\title{
Heritage, Nationalism and the Shifting Symbolism of the Wailing Wall*
}

\section{Simone Ricca}

\section{Q OpenEdition \\ 1 Journals}

\section{Electronic version}

URL: http://journals.openedition.org/assr/22401

DOI: 10.4000/assr.22401

ISSN: $1777-5825$

\section{Publisher}

Éditions de l'EHESS

\section{Printed version}

Date of publication: 1 September 2010

Number of pages: 169-188

ISBN: 978-2-7132-2255-9

ISSN: 0335-5985

\section{Electronic reference}

Simone Ricca, "Heritage, Nationalism and the Shifting Symbolism of the Wailing Wall* », Archives de sciences sociales des religions [Online], 151 | juillet-septembre 2010, Online since 20 October 2010, connection on 01 May 2019. URL : http://journals.openedition.org/assr/22401 ; DOI : 10.4000/ assr.22401 


\section{Simone Ricca}

\section{Heritage, Nationalism and the Shifting Symbolism of the Wailing Wall ${ }^{*}$}

While before 1967 Israel opted to create alternative "holy" sites ${ }^{1}$ to commemorate its establishment, the conquest of the West Bank and of the Old City of Jerusalem gave Israel the possibility to relate directly to the hard core of Judaism and its most celebrated symbols. A new interpretation of Jerusalem's physical townscape enabled the Israelis to turn a poor, run-down religious area in a showcase of the State's achievements, and into an Israeli stronghold shaped according to the will of the secular Ashkenazi elite. The multifaceted bonds linking heritage to nationalism, and ideology to the built environment, are embodied in the reconstructed Jewish Quarter.

The study of symbols, the creation of historic narrative, "invented" traditions, and heritage symbolism, have become common fields of study among Israeli researchers (Katriel, 1999; Zerubavel, 1995). Thus far, however, there has been no attempt to apply this approach to the physical transformation of a significant area of the Old City of Jerusalem. ${ }^{2}$

Carried out by the Israeli authorities after the 1967 capture of East Jerusalem, this transformation concerns in particular the "Wailing Wall", that segment of the outer compound of the Herodian Temple (and, by the same token, of the Muslim Haram al-Sharif) which since early modern times has been a religious focus for Jews. Yet these changes, which seek to erase a centuries-old Arab past

* A preliminary version of this article was reviewed by Ms. Linda Butler of the Institute of Palestine Studies. The article was first published in Jerusalem Quarterly File, issue 24, Summer 2005 (abstract available on the online edition).

1. New secular symbols were created in the western part of Jerusalem where traditional religious landmarks were not to be found: the zone of Givat Ram was selected as the site for public administration and institutional buildings, while Mount Herzl became a national memorial, a kind of alternative pilgrimage site, in the new Israeli city. The process of symbol creation was completed when the Yad Vashem memorial, commemorating the shoah, was inaugurated in 1959. With it, the State of Israel created for itself a "holy place" of its own in West Jerusalem, a counterweight to the traditional sites that remained in the eastern, Jordanian-controlled part of the city (Golani, 1999: 567-604).

2. With the notable exception of Nadia Abu El Haj's work (Abu El Haj, 1995; 2001). 
and replace it with a new, exclusively Jewish space adapted to the symbolism of a modern Jewish state, provide excellent grounds for such an approach. This paper proposes to examine both alterations to this space's meanings before 1967, as well as physical changes to the Wall area since that time. It also proposes to assess the extent to which recent efforts to make the Wall "the" Israeli national symbol, celebrating both Zionist values and Jewish religious tradition, have succeeded.

\section{The Beginnings of Tradition}

While the Wailing Wall today is universally acclaimed as Judaism's most sacred monument, its centrality to the religion is not as ancient as is commonly thought. We know from pilgrims and travellers in the fifteenth century that it was not the Wailing Wall, but the Mount of Olives outside the Old City that was dedicated once a year to the commemoration of the destruction of the Temple. ${ }^{3}$ The Wailing Wall area, a narrow courtyard (120 square meters) in front of the Wall enclaved within the fourteenth century Muslim Moroccan Quarter, was defined and set apart only during the reign of Ottoman Sultan Suleiman the Magnificent in the sixteenth century. F. E. Peters, in his comprehensive collection of travellers' and pilgrims' documents concerning Jerusalem, observes that only from the early years of that century did Jewish visitors describe the Wailing Wall and connect it with the earlier tradition of the "Presence of God." (Peters, 1985: 528). Even the "official" history of the Wall published by the Israeli defence ministry in the early 1980s, while noting that "literary reports of travellers and pilgrims, particularly in the last centuries, are full of descriptions of the Western Wall" added that "... it should, however, be pointed out that for hundreds of years, during nearly the whole of the Middle Ages, there is hardly any reference to the Wall” (Ben Dov, Naor, Aner, 1983: 65).

There is no question, however, that by the nineteenth century the Wall had become a central religious focus for Jews both locally and in the diaspora. Politicization of the issue began in the twentieth century, especially following the establishment of the British Mandate over Palestine at the end of World War I. District Officer L. Cust observed in 1929 that "in certain Jewish circles the right to pray has (...) become linked with the claim to actual ownership of the Wall" (Cust, 1980: 45). By that time, the secular Zionist movement, cognizant of the Wall's importance as a symbol, had begun to cultivate it in the service of its cause. As a result, it became the focus of growing tensions with the Muslim community.

3. Cf. the letter of the Italian Jewish pilgrim Rabbi Meshulam da Volterra who wrote in 1481: "And all the community of Jews, every year, goes up to Mount Zion on the day of Tisha Be-'Av to fast and mourn, and from there they move down along Yoshafat Valley and up to Mount of Olives. From there they see the whole Temple (the Temple Mount) and there they weep and lament the destruction of this House" (Nom De Deu, 1987: 82 - my translation, emphasis added). 
Tensions at the Wall are often marked as beginning in 1911, when the Ottoman Administrative Council officially resolved to forbid Jews from bringing chairs or screens for separating women and men into the narrow passageway in front of the Wall (Cust, 1980: 46). In fact, tensions clearly existed far earlier, as evidenced by an 1840 decree by Ibrahim Pasha forbidding Jews to pave the passage in front of the Wall (Löfgren, Barde, Van Kempen, 1930: Appendix VII). In principle, the conduct of worship and the maintenance of the holy places in Jerusalem were regulated by the Status Quo arrangements, established by the Ottomans in the mid-eighteenth century and confirmed by the great powers in the Treaty of Paris signed in 1855 (Berkovitz, 2001: 12), to reduce tensions and mitigate rivalries over holy places among the religious communities. ${ }^{4}$ Though these particularly concerned the Christian holy places, traditionally they embraced practices at Jewish holy sites as well, and were formally extended to the Wailing Wall and to Rachel's Tomb by the British during the Mandatory period. Nonetheless, Jewish challenges to the Status Quo at the Wall continued and escalated throughout the 1920s (Lundsten, 1978). The resulting tensions culminated in the outbreak of violence known as "the Wailing Wall incident" in August 1929 (Dumper, 1997: 200), when a demonstration at the wall by militant Zionist groups triggered rioting that resulted in the death of 133 Jews and 116 Arabs.

As a result of the Wailing Wall riots, in May 1930 Britain appointed, with the approval of the League of Nations, an International Commission of Inquiry for the Wailing Wall. The Commission's report, presented in December 1930, noted that while the "Jews do not claim any proprietorship to the Wall or to the Pavement in front of it [emphasis added]", the commission nonetheless intended "to inquire into the question of legal ownership as a necessary basis for determining the legal position in the matter". In its final conclusions, the Commission determined that the Jews would have free access to the Wall "for the purpose of devotions at all times" (though subject to enumerated stipulations) but that "to the Moslems belong the sole ownership of, and the sole proprietary right to, the Western Wall" as well as to the pavement in front and the adjacent Moroccan quarter (Löfgren, Barde, Van Kempen, 1930). The conclusions of the Wall Commission were accorded the status of law-the King's Order-in-Council on Palestine (Western or Wailing Wall), 1931-and incorporated by the Mandatory Government as an integral part of the Status Quo of the Holy Places (Berkovitz, 2001: 26).

Despite official prohibition by the Mandate authorities, Jewish national rallies continued at the Wall throughout the 1930s and 1940s. The growing confidence of the Zionist movement was apparent even at the time of the 1930 Wall Commission, particularly evidenced by the suggestion of the Jewish committee

4. For a brief chronology relative to the "Status Quo" arrangements, see Survey of Palestine, 1991: 899-900. 
chosen to meet with the Commission ${ }^{5}$ that the entire Moghrabi quarter, constituted entirely by waqf (religious endowment) properties, be vacated. In the eyes of the Arab committee formed to meet with the Commission, this demand "shows that the real intentions of the Jews are to lay hands by degrees on the Holy Places of the Moslems and to become the masters of the country" (Löfgren, Barde, Van Kempen, 1930: The Moslem Contentions -f-).

\section{Competing Traditions}

With the increased centrality of the Wall for Jews, new symbolic meanings and traditions were attached to the site. Though its importance, as noted above, had been growing during the second half of the nineteenth century, its significance remained primarily "religious", and some secular Zionists even found the sight of Jews praying at the wall disturbing, redolent of backwardness. Ahad Ha'am, one of the most prominent of the early Zionist pioneers, wrote in the 1880s: "as I stand and look at them, a single thought fills my mind. These stones bear witness to the destruction of our land, and these men to the destruction of our people. Which of the two catastrophes is the worse? Which gives greater cause of mourning?" (Hertzberg, 1996: 157).

By the beginning of the twentieth century, however, what had once been a purely "religious" site was being transformed into a nationalist issue, and the Wall began to be celebrated by both orthodox and secular Zionists. It is true that, as Akiva Orr has noted, the Wall was experienced very differently by the two groups (Orr, 1983: 193), and their differing attitudes constituted a source of conflict between them throughout the mandate period. Still, the Zionist movement from the very outset realized the evocative power of the Wall and capitalized on it; the delegate cards for the early Zionist Congresses had the image of Jews praying at the Wall on one side and the modern image of a pioneer working the land on the other. ${ }^{6}$ Moreover, the mingling of religious and national symbolisms increased. A 1935 Zionist tourist guidebook describes the commemoration of Tisha B'Av, the date that traditionally commemorates the destruction of the first and second Temples, as follows:

5. The committee included representatives of the Rabbinate of Palestine, the World Association of Rabbis, the Jewish Agency, Vaad Leumi and Agudat Israel.

6. Rachel Arbel has observed how the seemingly antithetical symbols are in fact complementary: "The praying Jews represent the impotence of the Diaspora and a focus on the past. Yet these opposites are complementary and interdependent: the pioneer relies on tradition, on generations of Jews who yearned for Zion, and draws his strength from them, while the traditional Jew has no hope and future without the pioneer. (...) The use of emblematic images that were both contradictory and complementary reflects the attempt of Zionist propaganda to mitigate the revolutionary shock of national revival, to make room both for those eager to change the face of Jewish culture and society and for those who wished to preserve the old frameworks and traditions." (Arbel, 1998: 22-23). 
"But the deepest impression is made by the Eve of Tisha be'Av (...). That evening a veritable Jewish migration to the Wailing Wall sets in after dark. The thousands slowly and silently pass before the everlasting stones far into the night; young and old, believer and free-thinker, the Old Yishuv from the Street of the Jews and the Halutzim from the colonies and Kvutzot. And if anywhere at all, here and at this hour you can feel that am Israel khai, Israel is Alive." (Kloetzel, 1935: 21).

Israeli sources emphasize the fact that in the same period, and as a reaction to the growing Jewish interest in the Wall, a Muslim counter-narrative developed celebrating the religious narrative of the sanctity of the tethering place of al-Buraq, the Prophet's magical steed. The Israeli Defence Ministry publication dates this tradition to the mid-nineteenth century (Ben Dov, Naor, Aner, 1983: 62), while alternative earlier locations for Buraq's tethering place are listed in Elad's Medieval Jerusalem and Islamic Worship (Elad, 1995: 99-104).

Though it appears evident that new attention was accorded to the al-Buraq tradition in the early twentieth century, and a sort of planned development of this "tradition" was staged by the Muslim religious authorities to counteract the Jewish/Zionist claims, relatively ancient traces of the association of the site with Muhammad's magical steed do exist. A fourteenth century manuscript by Ibn Furkah (d. 1328) states that al-Buraq was tethered outside Bab al-Nab, an old name for a gate along the south-western wall of the Haram al-Sharif, located at the very spot presently known as al-Buraq (Khalidi, 1997: 216, footnote 25). Wilson's map of Jerusalem of 1865 names the area around the Wailing Wall "Hosh al-Buraq" (Wilson, 1876 and Tibawi, 1978: 46), and the 1840 Deliberation refusing the Jews the right to pave the area in front of the Wall already defines it as "the spot where al-Buraq was tethered" (Tibawi, 1978: 20).

Following the 1948 War and the expulsion of the Jews from the Old City, the role of the Wall changed again: the Jordanian Authorities tried to minimize the Jewish relevance of the site and stressed its uniquely "Arab" connotation. This is visible, for example, in a Jordanian-period postcard ${ }^{7}$ portraying a Palestinian woman in "traditional" dress walking by the Wall. ${ }^{8}$

\section{June 1967: Erasing the Past}

With Israel's 1967 conquest of East Jerusalem, a dramatic transformation took place. Immediately after the battle for the Old City ended, the entire Moroccan Quarter was razed, and its 650 inhabitants were evicted with only three hours to remove their belongings. ${ }^{9}$ The section of the Wall dedicated to prayers was

7. The original colour postcard is reproduced in black and white in al-'Alami (1981: 263).

8. The dress portrayed in the postcard seems typical of the north of the West Bank and not of Jerusalem, but ethnographic accuracy was not necessary because foreign tourists were the "target" of this highly symbolic image.

9. The destruction of the Moroccan Quarter has been detailed by the foreign press and by foreign and Palestinian commentators (Dumper, 1997: 162). 
extended southwards to double its original length from 28 to 60 meters, while the original facing open area of some four meters grew to 40 meters: the small 120 square meter area in front of the wall became the vast Western Wall Plaza, covering 20,000 square meters over the ruins of the Moghrabi Quarter (Berkovitz, 2001: 27).

This radical transformation of the urban landscape, in clear violation of the Geneva Convention ${ }^{10}$ not to mention the Status Quo understandings, was decided jointly by the military and civil authorities and later officially attributed to mayor of Jerusalem Teddy Kollek. ${ }^{11}$ The reasons for this move, which dramatically marked the symbolic appropriation of the city by the Israelis, have been analyzed by Meron Benvenisti ${ }^{12}$ and by Uzi Benziman ${ }^{13}$, but its long-term impact on the city, its residents, and foreign visitors often goes unmentioned.

The millions of tourists who have visited Jerusalem since 1967 have no idea of the site's previous layout; Israeli tour-guides generally avoid any mention of the Moroccan Quarter and its razing immediately after the June war. ${ }^{14}$ Thus this erasure was not only physical, but one of memory as well: the many publications about the Old City almost never include photographs of the site as it used to be. Even the few available images of the Moroccan Quarter sold in the Old City photography shops date from the beginning of the century, therefore promoting a convenient confusion between the destruction caused by the 1948 fighting and the deliberate erasure of the neighbourhood in 1967. This erasure, to an extent, applies even to the younger generations of Palestinians who have

10. The Geneva Convention of 1949 , signed and ratified by Israel on August $12^{\text {th }} 1949$, art. 53, prohibits: "The destruction by an occupying power of moveable and immovable property, except where such destruction is rendered necessary by military Operations".

11. A recent unpublished report by Daniel Seidemann (2007: 4-5) details the demolition of the Moroccan Quarter and presents a copy of the original hand-made sketch, drawn by an Israeli architect, designing the area to be demolished.

12. "Despite the justified criticism, the act itself was seemingly inevitable. The Wall area could not hold the hundreds of thousands who wished to come in 1967. Beyond the overwhelming practical considerations, however, an irrational impulse was at work. The move was the settling of an historic account with those who had harassed the Jewish People over the centuries, restricting and humiliating it at its holiest place, as well as with those who had prevented access to the Wall for 19 years. The displaced inhabitants of the Moroccan Quarter were not personally to blame, but it was their fate to be additional victims of the Arab-Israel conflict." (Benvenisti, 1976: 307).

13. Haaretz journalist Uzi Benziman wrote that those in charge of bulldozing the Moghrabi quarter, who speeded up the operation to avoid challenges: “... realized that their action was motivated neither by security considerations nor by town planning. They were driven by some mysterious feeling that they represented the Jewish people, that they were asserting Jewish sovereignty over its most sacred place" (quoted in Tibawi, 1980: 184-85).

14. As an example of this attitude, on February 9, 2002, I was part of a guided tour (mainly composed of members of the International Diplomatic Community) of the Jewish Quarter led by the well-known author of an archaeological guide to the Holy Land. Not only did he not mention the previous existence of the Moroccan Quarter in his description of the Wailing Wall area, he even stated that the whole area up to the Wall has always belonged to the Jews. 
grown up knowing only the vast, empty Plaza-and this despite the fact that many Palestinian families in the Old City have relatives who used to live in the Moroccan Quarter ${ }^{15}$ or in nearby buildings demolished to make way for the greatly expanded Jewish Quarter. ${ }^{16}$ Over the past 35 years, the new Plaza and the totally revamped Jewish Quarter have become "traditional" features in a city where Arabs and Jews speak different languages, live in separate worlds, and do not intermingle. ${ }^{17}$

The depiction of the Moroccan Quarter as a jumble of hovels (when it is referred to at all) almost immediately became the official truth. ${ }^{18}$ According to a foreign resident of the Old City:

"The day the bulldozing began the quarter was described in The Jerusalem Post as a slum. Two days later it was reported as having been by and large abandoned during the siege. I expect in time that its existence will vanish altogether from the pages of developing Zionist history." (Schleifer, 1972).

These ideologically-motivated depictions are refuted by descriptions culled from contemporary reports, interviews with former inhabitants (Abowd, 2001), and old photographs of the quarter, all of which testify that the ancient medieval quarter was a lively neighbourhood, its level of dilapidation mirroring that found elsewhere in the Old City.

The following step in "clearing" the area, the demolition of the Abu Saud complex ${ }^{19}$ in front of Bab al-Magharibah, took place two years later in June 1969. An example of Mamluk architecture and a well-known element of the

15. One hundred and thirty five houses and two mosques were demolished.

16. The large-scale reconstruction project of the area that forms today's Jewish Quarter is not the subject of this article, but it might be useful to remember that in March 1968, 29 acres (including the area of the demolished Moroccan Quarter) of the Old City were expropriated by the Israeli authorities to create the new Jewish Quarter and that, according to Meron Benvenisti, Jewish-owned property before 1948 comprised no more than $20 \%$ of the Quarter (Benvenisti, 1976: 239). The political implications of the reconstruction plan of the new extended Jewish Quarter are discussed in Re-inventing Jerusalem, The Reconstruction of the Jewish Quarter after 1967 (Ricca, 2007).

17. Edward Said has noted that the now-dominant Israeli narrative on Jerusalem has been able: "... to project an idea of Jerusalem that contradicted not only its history, but its very lived actuality, turning it from a multicultural and multireligious city into an 'eternally' unified, principally Jewish city under exclusive Israeli sovereignty." (1995: 7). For the religious syncretism in Ottoman Jerusalem, see also Tamari, 1999.

18. See, for instance, Teddy Kollek's and Ben Dov's books (Kollek, 1978: 197; Ben Dov, 1983: 36).

19. That included the Fakhriyyah zawiya and the Abu Saud living quarters. It might noteworthy to remember that the mother of the Palestinian leader Yasser Arafat, Zahwa Abu Saud, was a member of the Abu Saud family. The Israeli journalist Danny Rubinstein writes in his biography of Arafat: "It is doubtful that Yasser Arafat witnessed the demolition of the house, but, on the few occasions he has spoken of his childhood, he mentioned the destruction of the Abu Saud house along with vague hints and fragmentary remarks on childhood memories from Jerusalem. As far as we can ascertain, Arafat did live in this house from 1933 to 1936, from the age of four to seven. Perhaps he visited it on a few occasions afterwards." (1995: 21-22). 
city landscape and history was removed to enlarge the excavation area and to "free" access to the Haram al-Sharif for the Israeli army in case of troubles. In this case too, the tendency to downgrade the architectural and historic value of "inconvenient" buildings is evident in the above-mentioned Defence Ministry publication's description of the buildings:

"Even the remaining houses on the outcropping are unimportant. Although some date from the Middle Ages, extensive reconstruction has been done in them in the $20^{\text {th }}$ century. One of them has a concrete roof supported by iron railways tracks! The balconies of the buildings are also constructed of railways tracks which proves conclusively that they do not predate our century. The presence of these buildings in the area is purely accidental; a decision to remove them would be just as legitimate as one to leave them there." (Ben Dov, Naor, Aner, 1983: 167) ${ }^{20}$.

This strategy of purposeful depreciation of the non-Jewish heritage of the city can be seen in several developments involving the Wall. After the 1967 capture of the Old City, Jewish religious personalities pushed for "freeing" the entire length of the 465-meter wall, proposing the demolition of all the Islamic theological colleges (the Mamluk madrasas built along the outer wall of the Haram al-Sharif constitute one of the pre-eminent architectural features of the old city of Jerusalem ${ }^{21}$ ) and Arab-inhabited buildings that had grown along it during the centuries.

The case that caused the greatest controversy involved the "Little Wall", the only segment of the Western Wall (aside from the extended Wailing Wall) unobstructed by later construction. Located in the courtyard of the thirteenth century Ribat al-Kurd, a Mamluk period hospice near Bab al-Hadid, the wall was "discovered" by Jewish religious groups during 1971/2. Though no previous Jewish worship was attested there (Rabinovich, 1972: 9), they began to pray at the site and tried to take over the property. Referring to an "ancient tradition"-for which no evidence was produced-the site was quickly baptized the "Little Kotel" to emphasize its connection with the Wailing Wall. ${ }^{22}$ In this context, it is important to note the distinction between the Wailing Wall and the Western Wall. The International Commission established in 1930 to investigate the "Wailing Wall", for instance, specified that the "part of the wall about which dispute has arisen between the Jews and the Moslems" (i.e., the "Wailing Wall”) is about 30 meters long (Löfgren, Barde, Van Kempen, 1930); the tendency to equate the two since the 1967 War appears to coincide with expanding claims (these terms will be discussed in more detail below).

20. Though the book was published in 1983 , it is evident that this chapter pre-dates the demolition of June 1969.

21. For a complete historic and architectural record of these monuments, see Burgoyne, 1987.

22. In his analysis of Ribat al-Kurd, Michael Burgoyne suggests that the lower part of the outer face of the Haram in the building's courtyard belongs in fact to the Umayyad rebuilding of the wall and not to the Herodian period (Burgoyne, 1987: 150). 
Meanwhile, excavations along the Wall to open an underground "tunnel" and uncover the underlying Herodian stones, initiated in 1967 with the approval of the Ministry of Religious Affairs, had caused serious damage to the same Ribat al-Kurd and to some of the finest examples of Mamluk architecture in the Old City. Digging was ordered halted. In the 16 February 1972 Knesset debate concerning the damage, most speakers-using language and rhetorical technique reminiscent of those used for the Moroccan Quarter-demanded that the entire length of the Western Wall be cleared. The Ribat al-Kurd was presented as a "slum" with no "historical significance". ${ }^{23}$ Rabbi Meir Kahane, leader of the extremist Kach party, questioned the authority of the archaeologists that the municipality had hired to assess the "historicity" of the Arab structures in relation to the Jewish "historicity" of the Wall. What was at stake was in fact the role of heritage in shaping the city's future.

\section{Heritage and History}

The symbolic significance of these changes and attempted changes might be better understood with reference to the concept of "heritage" as defined by David Lowenthal in The Heritage Crusade. Lowenthal distinguishes between "History", the past that actually happened, and "Heritage", the past manipulated for some present aim $^{24}$ :

"Heritage links us with ancestors, certifies identities, builds collective pride and purpose, but in so doing stresses distinctions between good guys (us) and bad guys (them). Heritage faith and heritage rhetoric inflame enmity" (1998: 248).

The very definition of Israel as a "Jewish State" implies that its national heritage must be a "Jewish Heritage". It can easily follow, then, that all that is not specifically "Jewish" might (or should) be removed. New "facts" can be created that compete with those sought to be minimized—or the urban landscape can simply be demolished and replaced with a more suitable one, as in this case. Other questions to be pondered are those raised by Turndridge and Ashworth in the preface of their 1996 Dissonant Heritage, where they say: "we will never again look at a monument or exhibit without posing not only the 'Whose heritage is this?' question, but also the insistent Who is disinherited here and what are the consequences of such dispossession?" (Tunbridge, Ashworth, 1996: xi).

23. Dr Zerah Warhaftig, then Minister for Religious Affairs, said that “... the Arab families were suffering in their homes along the Wall ... (and) children could not grow properly under such conditions". Menachem Begin spoke of "ramshackle houses to be cleared”, while Dr Yitzhak Raphael declared that the buildings "had no historical significance" (Jerusalem Post, 14 February, 1972, 7).

24. Other authors push further the debate and question the very nature of "history" by inserting a three-level system separating the "past" (what has happened) from both "history" (selective attempts to describe this) and "heritage" (a contemporary product shaped from history) (Tunbridge and Ashworth, 1996: 21). 
The answers, in the case of the Wall, are obvious: Palestinian heritage has been erased, both from the physical map and from the map of memory, and the consequences of this dispossession have buttressed Israeli claims to the city. Plans for the Wall area have managed to erase from centre stage the complexity of history and the embarrassing presence of other people's heritage.

Israel's efforts after 1967 to present an image of Jerusalem in keeping with its political aspirations and vision of history (and thereby bolster principles like "the unity of the Jewish people" and its "necessary realization in the Jewish State") entailed a large propaganda effort to celebrate the Wall and highlight its importance for Judaism. Pseudo-scientific books on the Jewish Quarter and the Wall were published, ${ }^{25}$ while new "traditions" centred on the Wall were developed. In a Jerusalem Post article of 1971, for instance, we read:

[...] Tisha B'Av at the Western Wall is becoming ever more an international Jewish Holiday [emphasis added] and ever less a day of mourning. To the tens of thousands of Israelis and tourists who swarmed to the Old City last night when the fast commenced, The Wall was obviously more of a reminder of the Israeli victory four years ago, than of the Jewish defeat and destruction of the Temple 1901 years ago (Landau, 1971: 13).

But in order to become the "universal" and "eternal" symbol of Judaismand in so doing strengthen the link with the Jewish Diaspora and forge a unity between the diverse components of Israeli society (secular and religious, Ashkenazi and Sephardi, Ultra Orthodox and Reform) - it was necessary to mute alternative Jewish traditions as well as critical voices objecting to the "worship of stone" or the partition between men and women at the Wall. ${ }^{26}$ In other words, the symbolism of the Wall had to be "adapted". Linguistically, this change is represented by the rejection of the traditional term "Wailing Wall", with its emphasis on what has been lost, and its substitution with the more neutral "Western Wall" (which is also conveniently ambiguous, designating, as it does, both the entire western wall of the Temple Mount/Haram al-Sharif compound and the area traditionally set apart for prayers). At the rhetorical level, the locus shifted from the destruction of the temple to the themes of national renaissance.

This strategy, commenced in the 1920s, has been highly successful, and since the June 1967 victory, the Wall has undoubtedly become the central altar of

25. See, for instance, the review by L. Abramovich of a book by A. Rivin where we read: "With the renovation, reconstruction and repopulation of the Jerusalem Old City's Jewish Quarter in the last five years, there has been a revived interest in the history of Jerusalem. (...) Many books have appeared describing people and periods of Jerusalem history. (...) Perhaps the greatest contribution of such works, as the late Ben Gurion wrote in an introduction to the book is that they make it possible for our youth to 'know that Israel's establishment did not begin with the declaration of the State'. This book, and all the others of this genre, is a good reminder that there were always Jews living here." (Abramovich, 1974: 13).

26. This was, for instance, the approach of the Judaism Reform Movement. A gendercentred analysis of the Wall, discussing the evolution of Jewish rituals, has been recently published by Stuart Charmé (2005). 
the Israeli state. This success has not been welcomed by all. Israeli philosopher Yeshayahu Leibowitz, for example, noted in an interview: "Twenty years ago, neither those who practised the mizvot nor, obviously, those who did not, paid attention to or even thought about the Western Wall. Why, after 2000 years of Jewish life, should a new Judaism suddenly appear, seven days after the Six-Day War, with the Western Wall?” (Storper-Perez, 1989: 98 [my translation]).

For the most part, however, religious and secular Israelis accord extraordinary importance to the Wall as both a sanctuary and a monument. ${ }^{27}$ This carefully planned double dimension is physically represented in the plaza. The space in front of the Wall is composed of two distinct zones: the area closest to the wall, for prayer, is the focus of traditional religious devotion and falls under the aegis of the rabbinate. The more distant expanse of the plaza, controlled by the government, became the representation of Israeli "civic religion": military parades, swearing-in ceremonies, commemoration of the soldiers fallen in war, Jerusalem Day, and so on.

Further, emphasizing the "sanctity" of the Wall area allowed the Israeli government to divert attention from the (in its eyes) highly problematic site of the Haram al-Sharif, which remained in Muslim hands. The Wall was officially transformed into an open-air synagogue and the minister of religious affairs explicitly declared it a holy place. Not only the Wall was declared "holy" under the new regulations, but also the prayer square in front of it "including any structure or passage above or below ground whose entrance is through the prayer square" (Berkovitz, 2001: 20-21).

One of the tools used in establishing this consensus and underscoring the new "secular" value of this site has been-as so often in Israel-archaeology. It was hoped that through archaeology the Jewish right to the land could be affirmed and traces of the Arab past erased (as in June 1969 when the Abu Saud complex in front of Bab al-Magharibah was demolished in order to uncover a Herodian road). In fact, however, the archaeological excavations at this extremely sensitive site aggravated tensions between secular and religious Israelis, demonstrating the delicate balance needed between the diverse elements with which the state was playing and the fragile nature of their consensus over the celebration of the Wall.

The extensive excavations directed by Prof. Mazar of Hebrew University between 1968 and 1977 near the southwest corner of the Haram, which uncovered the remains of previously unknown Umayyad palaces, became the focus of a long-lasting "battle" between the archaeologists and the rabbinate. These hostilities were exposed when a decision was made to set aside a section of the Western Wall for archaeological excavation, and intensified as soon as the excavations extended northward along the wall towards the Wailing Wall and the prayer area controlled by the Ministry of Religious Affairs (Rabinowitz, 1969).

27. According to a survey (Katz, Levy, Segal, 1997) 97\% of Israeli Jews consider Jerusalem, with the Wall at its centre, important as the "symbol of Israel". 
The tension between archaeologists and the religious establishment reached its peak in 1972, when the archaeologists demolished the building housing the Supreme Rabbinical Court (originally a Girls' School built by the Jordanians in the early 1960s) in order to enlarge the dig. ${ }^{28}$ Other simultaneous occurrences showed the incompatibility of the two groups: the ongoing "unofficial" excavations at the "tunnel" carried out by the Ministry of Religious Affairs without archaeological supervision, and the polemics surrounding the excavation of Jewish graves by archaeologists, considered unacceptable by the religious authorities and by part of the religious public. The un-aesthetic "outcropping" leading to Bab al-Magharibah, resulting from the June 1969 demolitions described above, also should be viewed in this context. This area plays the role of frontier between two parts of the very same wall: one set apart for secular needs, and one for religious worship. The state, a third oversight body, acts as an arbitrator and maintains control of the gate for "security" needs. ${ }^{29}$

\section{New Trends and the Shifting Symbolism of the Wall}

Efforts to shape the link between ancient past and present rebirth through architecture and planning have met with obstacles. Though the large esplanade and the rebuilt Jewish Quarter conveyed to hundreds of thousands of citizens and tourists the clear message of Israel's control over the city, fear of disrupting a precarious equilibrium has prevented the implementation of any comprehensive architectural plan for the plaza. No design for the area, in fact, has ever received the approval of both the secular and the religious establishments, and after more than 30 years the large esplanade remains an open, shapeless and empty scar in the heart of the dense urban fabric of the city.

The two best known design proposals for the Wailing Wall Plaza were prepared by the internationally renowned architects Moshe Safdie and Isamu Noguchi

28. On the polemics surrounding this decision, see the articles on The Jerusalem Post by David Landau (1972a, 1972b and 1972c).

29. Bab al-Magharibah is the only access to the Haram al-Sharif under full Israeli control. It is considered essential by the Israelis to secure the control of the Haram as it facilitates access for police and army intervention. The precarious status quo that developed at the site has been altered by the sudden collapse, on February 2004, of the Moghrabi Gate ramp. While a temporary wooden ramp has rapidly been built over it, pressure has mounted from various Israeli political groups for the construction of a new permanent access ramp larger and longer than the original one. The actual plan for such a structure was approved by the Israeli authorities in 2006, but has not (yet?) been implemented following strong national and international criticisms. The main actors of the debate that developed on June 28, 2006 in the Prime Minister's office concerning this project were: the Police, the Rabbinical Authority, the General Security Services, the Israel Antiquities Authority and the Western Wall Heritage Foundation (Seidemann, 2001: 12). The presence of the Western Wall Heritage Foundation, an association closely linked to the Old City settler groups, in the debate shows that the State does not play anymore the role of an external arbiter, but has instead partially integrated the agenda of these groups for the Wailing Wall area. 
in the 1970s. Safdie's plan-supported by the Israeli Jerusalem municipality and heavily influenced by economic considerations and archaeological findsproposed a complex system of multi-level terraces and stairs leading down to the original basis of the Wall, some ten meters below the present level. Isamu Noguchi's proposal, on the other hand, stressed further the symbolic relevance of the site for all Jews by proposing the creation, in front of the Wall, of a monument to the Holocaust-a large irregular block of black basalt. Though extremely different in scope and sensitivity, both designs are based on the ideological assumption that the site has an exclusively Jewish significance.

But among Israeli Jewry, the goal of transforming the Wall into a unifying symbol has substantially failed. In the last 30 years Israeli society has grown more and more differentiated and internally divided; symbolism around the Wall has evolved along with these changes and the blossoming of religious/messianic movements.

A fracture between the planned "national" symbolism attributed to the Wall and its actual use was already apparent in 1974, when, after a few years of growing secularization in the commemoration of Tisha B'Av, the traditional character of the celebration re-emerged, as indicated in press accounts. ${ }^{30} \mathrm{With}$ the fading of "civil religion" and of the Zionist narrative, the Wall has been reappropriated by new religious communities ${ }^{31}$ and other trends have developed in connection with this religious re-appropriation. By this, I refer to the shifting of attention from the Wall itself to the Haram al-Sharif and to the proposed reconstruction of the Temple on the site of the Muslim mosques.

The "master commemorative narrative" 32 that created the Wall plaza and the new Jewish Quarter as the symbol of continuity between the ancient past and the modern Jewish state persists, but is now shared by a different constituency. This new "Jewish" community (including a large group of foreign bornagain Jews) that has developed within the quarter itself no longer pays much attention to archaeology or to celebrating the heroism of the quarters' defenders in the 1948 battle. Rather, it longs for the "dream" of a new temple.

The physical environment of the Jewish Quarter has therefore changed to adapt to new needs and values. This is particularly evident in the restored Byzantine Cardo. What was planned as the main tourist-commercial axis of the rebuilt quarter, with a didactic reconstruction of the original wooden roofing of the shops of the ancient street, has been transformed into an exhibition hall for the reconstructed vessel of the Third Temple.

30. The Jerusalem Post detailed this evolution in a series of articles: "It seemed that, as daylight broke through, the traditional pattern of mourning that has marked Tisha B'Av through the ages had resurfaced again." (Siegel, 1974: 2).

31. Already in 1974, Geula Cohen said that the Wall was "a symbol of spiritual power which could cure the ills of the sick nation." (Anonymous, 1974: 3).

32. According to the definition of Yael Zerubavel (1995). 
In 1983, when discussing the issue of the planning of the Wailing Wall Plaza, Meir Ben Dov underlined the Wall's function as "surrogate" temple:

"Prayer at the Wall became important as a result of a compromise-because the Temple is not rebuilt-but cannot, in any way, serve to transfer the spotlight form the centre to the periphery. No matter how holy its tradition has become for many but such a status is not within Jewish tradition. Any design for the Wall area must, therefore, realize that the Wall does not represent the achievement of Judaism's ultimate hopes; that will be in the rebuilding of the Temple however theoretical that may be and however delayed it may be till the arrival of the Messiah." (Ben Dov, Naor, Aner, 1983: 16).

With the growing political influence of extremist religious groups and Israel's ability to maintain its hold on the entire city, more and more individuals have begun to reconsider the role of the Wall and turn their gaze towards the Haram al-Sharif, site of the planned third temple, as they await its miraculous transformation.

To underline the differences between mainstream Judaism and contemporary ultra-orthodox groups in their perspective of the temple, we might compare the late nineteenth century mizrah ${ }^{33}$ which shows the Dome of the Rock with its Muslim crescent under which is written in Hebrew "The site of the Temple" (Ben Dov, Naor, Aner, 1983: 198), with the oft-reproduced poster depicting a rebuilt Third Temple replacing the Muslim holy shrines, which is sold in many Jewish Quarter bookshops.

\section{Evolution: Towards a New Synthesis of Zionism and Tradition?}

Since the end of the 1990s, a new evolution is taking place in the Jewish Quarter: the revitalization of some out-moded Zionist symbols by the successive rightist Israeli governments. Possibly worried by the excessive focus on the Temple and its reconstruction, Israel's rightwing governments are attempting to establish fresh bonds between Zionist and religious values. The new public relations offensive is evident in a number of plans, presently at various stages of implementation, whose goal is the revitalization of the reputation and of the cityscape of the Jewish Quarter and the Wall plaza.

The most important among them, for its symbolic role, is the project for the reconstruction à l'identique of the nineteenth century Hurva Synagogue, the "heart" of the Ashkenazi community in the pre-1948 Quarter. While a similar plan-favoured by Menahem Begin when he was Prime Minister-was refused in the late 1970s by the architects and planners designing the new quarter (who

33. Mizrah means "East" in Hebrew, but the word is used also for the traditional Jewish engraves (mostly featuring the word mizrah in Hebrew in the center) that were hung on the eastern wall of a home to indicate the direction in which to pray. 
preferred, instead, to consolidate the ruins of the synagogue as a memorial to the quarter's 1948 destruction), in the new political framework:

"A public committee formed in 2002 by the Minister of Housing, Rabbi Yitzhak Levi
and headed by Rabbi Simha Kook, decided to restore the Hurva to its previous glory.
Mr Dov Kalmanovitch, chairman of JQDC's board and Mr Yinon Ahiman, the
company's CEO, the Minister of Housing Mr Nathan Sheransky and his successors
Ministers Effy Etham, Tzipi Livni, Ze'ev Boim, Yitzhak Herzog and Meir Shitrith all
harnessed themselves to the successful completion of the project. Past and present
mayors of Jerusalem, Mr Ehud Olmert and Mr Uri Lopliansky and substitute mayor
Rabbi Jehoshua Pollack are all enthusiastic supporters of the project." (CDRJQ, http://
www.jewish-quarter.org.il/churva-malacha.asp).

The reconstruction of the 24-meter high dome of the Hurva is certainly going to transform the image of the neighbourhood and the rebuilt synagogue might become a new focal point for the religious community of the Jewish Quarter. Nahum Miltzer, an Israeli architect, has prepared the plans for the reconstruction in cooperation with the Israeli Antiquity Authorities. The project implementation started in 2006 and is scheduled to end by $2011 .{ }^{34}$ In the official presentation of the project, architect Metzer affirms that the actual raison d'être of the reconstruction is that the Hurva Synagogue "beyond all considerations of the quality of the building (...) is connected to the historic memory of the Jewish People." 35

To this same new trend we might ascribe also the recently completed refurbishment of the Wall plaza (with the construction of stone-faced arcades along its northern side), the planned enhancement of the archaeological exhibitions of the Jewish Quarter and the creation of a new archaeological/religious attraction, the Davidson Virtual Centre. This new "museum", ${ }^{36}$ whose design skilfully makes use of some of the ruins of the archaeological garden near Dung Gate, is dedicated to Jerusalem and pilgrimage to the Jerusalem Temple in Herod's time. With the support of high-tech computer graphics and virtual models, the visitor is introduced to a virtual reality where everything is Jewish, where no "foreign" elements perturb the scene. This extremely selective representation of a single moment in the long and complex history of the city, though based on archaeological data and probably scientifically correct, conveys an obvious political message. It presents a mythical ancient city whose virtual houses bear an unexpected resemblance to the reconstructed Jewish Quarter buildings.

34. In 2002, the Israeli government allocated six million dollars for the reconstruction. On February 2004, the Israeli Antiquities Authority had almost completed the salvage excavations on the site and the plan had received most of the official approvals (Green, 2004).

35. Cf. the official website of the Company for the Reconstruction and Development of the Jewish Quarter.

36. More than a museum, in fact, it is a "heritage centre", a museum without original artefacts, exhibiting only models and complex 3D computer simulations of the city before the destruction of the Temple by the Romans. 
The main difference between these newly planned transformations and the 1970s project for the Jewish Quarter seems to lie in their openly-stated connection with Jewish religious symbols. What proved an impossible task for Israeli governments in the seventies (i.e. the contemporary celebration of secular Zionist and traditional religious values) seems nowadays possible through an insistence on religious heritage and the partial playing down of nationalist-historic elements. Whether this new campaign will be able to divert the attention from the possibilities of a Third Temple, recreating a larger national consensus and interest in the Jewish Quarter of the Old City of Jerusalem is still too early to say, but it is obvious that these apparently minor transformations have in fact deep political meaning, and represent new symbolic steps in the continued Israeli takeover of the Old City of Jerusalem.

\section{Conclusion}

The city of Jerusalem developed for centuries within its city walls, keeping almost immutable characteristics while continuously renewing its physical structure. Due to the continuity in building techniques and materials, the Old City has been able to conserve its traditional image until the present day, the only notable exception being the new Jewish Quarter. The alien features introduced to this neighbourhood constitute an evident fracture amid the traditional Old City urban fabric altered previously only by the nineteenth-century Christian buildings constructed in "European" styles.

The military conquest of Jerusalem necessitated the city's physical transformation, in order to adapt a typical Middle Eastern, medieval and mainly Arab city to the symbolism and requirements of a modern Jewish state. The contrast between the mythical image of the city in Jewish prayers and in Zionist political expectations on the one side, and reality on the other, was too strong to sustain the claims of Israeli ownership: hence, the transformation of both the human and physical landscape of the Old City. The post-1967 Wailing Wall Plaza did not come about as the result of destruction wrought by war; rather, it is the embodiment of a national/religious programme aimed at underlining the eternal link of the Jewish people with the Holy City. The goal of the urban plans carried out by the Israelis in the Old City and in the area of the Wailing Wall, in fact, has been to erase the living memory of a non-recognized Arab/Muslim past (and present) and to replace it with a new space. The efforts to rebuild this environment as effective scenery for representing a new ruling power were carefully planned and embody the symbolic role the Israeli government attributed to the city. The Jewish Quarter plan, and the Wailing Wall Plaza, promote the claim to the land at the international level by conveying the message of Israel's right of possession to and its "enlightened" rule over Jerusalem. The area known today as the Jewish Quarter was designed to serve as a manifesto of the State of Israel and of its approach to history and heritage: not only a modern quarter 
or just another Jewish settlement in the city, but the actual incarnation of the ideology of the country.

Though the will to transform the cityscape and adapt it to the needs of the new rulers is a common feature in urban history, what makes the case of Jerusalem peculiar is that these acts have been presented to international public opinion as the "restoration" of the Old City of Jerusalem. With great ingenuity, Israel has been able to present itself as "restorer" of the city's heritage, enlightened "caretaker" of the holy sites and defender of the menaced urban fabric of the city.

The destruction of the Moroccan Quarter and the creation of the Wailing Wall esplanade in its stead, therefore, not only exemplify the strict relationship between architecture, planning, heritage, symbolism and nationalism, but moreover demonstrate Israel's overall ability to successfully re-write history according to its needs.

The reconstructed neighbourhood, however, was also planned to stress the cohesion of Israeli society and to promote the "national" dimension of the Jewish people, using urban reconstruction to achieve a synthesis between religious and nationalist traditions. The interplay of tradition and modernity, of secular socialist Israel and traditional Judaism, however, proved to be beyond the capabilities of the state to manage, especially when its ideological basis was shaken following the 1973 Yom Kippur War. The conscious use of religious symbolism, which the secular ruling class initially introduced, escaped their control, and the reconstructed Jewish Quarter increasingly developed along autonomous and partially unexpected lines, reflecting the wider transformation of Jerusalem's population and the evolution of Israeli society as a whole.

Simone RICCA

Chercheur indépendant

s.ricca@rcheritage.com

\section{Bibliography}

Aвramovich L., 1974, “Jews of Jerusalem the eternal”, The Jerusalem Post Magazine, 17 May.

АвоwD Tom, 2001, “The Moroccan Quarter: a history of the present”, Jerusalem Quarterly File, 7, pp. 6-16.

Abu El Haj Nadia, 1995, Excavating the Land, Creating the Homeland: Archaeology, the State and the Making of History in Modern Jewish Jerusalem, Duke University Department of Cultural Anthropology, PhD thesis.

-, 2001, Facts on the Ground: Archaeological Practice and Territorial Self-Fashioning in Israeli Society, Chicago, Chicago University Press.

Al Alami A., 1981, Waqfyiat al-Magharibah [The Waqfs of the Moroccans], Jerusalem, Da'irat al-Awqaf al-'Amma. 
Arbel Rachel, 1998, "Menorah and Magen David: The Evolution of Zionist Symbols", The Israel Museum Journal, 16, pp. 22-23.

Ben Dov Meir, Naor Mordechai, Aner Ze'ev, 1983, The Western Wall, Tel Aviv, Ministry of Defense Publishing House.

Benvenisti Meron, 1976, Jerusalem, the Torn City, Minneapolis, University of Minnesota Press.

Benziman Uzi, 1973, Yerushalaim, Ir lelo Homa [Jerusalem, A City Without Walls], Tel Aviv, Stocken.

Berkovitz Shlomo, 2001, The Temple Mount and the Western Wall in Israeli Law, Jerusalem, The Jerusalem Institute for Israel Studies.

Burgoyne Michael Hamilton, 1987, Mamluk Jerusalem, Amman, The World of Islam Festival Trust \& The British School of Archaeology in Jerusalem.

Charmé Stuart, 2005, “The Political Transformation of Gender Traditions at the Western Wall in Jerusalem", Journal of Feminist Studies in Religion, 21-1, pp. 5-34.

Company for the development and reconstruction of the Jewish quarter, Official website (last visited February 2010), "Building the Hurvah - Architect's Statement”, http:// www.jewish-quarter.org.il/churva-architect.asp

Cust Lionel G. A., 1980, The Status Quo in the Holy Places, Jerusalem, Ariel Publishing House (reprint of a confidential print dated September 1929).

Dumper Michael, 1997, The Politics of Jerusalem since 1967, New York, Columbia University Press.

ElAD Amikam, 1995, Medieval Jerusalem and Islamic Worship, Leiden, E. J. Brill.

Golani Motti, 1999, “Jerusalem's hope lies only in partition: Israeli policy on the Jerusalem question”, International Journal of Middle East Studies, 31-4, pp. 577-604.

GreEn David, 2004, "From the Ruins”, The Boston Globe, 29 February (internet edition). Hertzberg Arthur, 1996, "Jerusalem and Zionism", in Rosovsky N., (ed.), City of the Great King, Cambridge, London, Harvard University Press.

Katriel Tamara, 1999, "The Past in Israeli Pioneering Museums”, in Ben Amos D., Weissberg L., (eds.), Cultural Memory and the Construction of Identity, Ohio, State University Press, pp. 99-135.

Katz Elihu, Levy Shlomit, Segal Jerome, 1997, The Status of Jerusalem in the Eyes of Israeli Jews, Jerusalem, Guttman Institute of Applied Social Research \& Center for International and Security Studies, College Park, University of Maryland.

KHAlidi Rashid, 1997, Palestinian Identity: The Construction of Modern National Consciousness, New York, Columbia University Press.

Kloetzel Ceskel Zwi, 1935, The Way to the Wailing Wall, Jerusalem.

Kollek Teddy, 1978, For Jerusalem, a Life, Jerusalem, Steimatsky.

LANDAu David, 1971, “70.000 at Western Wall; little mourning observed”, The Jerusalem Post, 1 August.

-, 1972, "Demolition order against Supreme Rabbinical Court", The Jerusalem Post, 16 October, p. 12.

-, 1972, "Religious Court still sitting in its building declared unsafe", The Jerusalem Post, 4 November, p. 7.

-, 1973, “Old Rabbinical Court by Western Wall coming down", The Jerusalem Post, 3 January, p. 8. 
LÖFgren Eliel, BARde Charles, VAN KEMPEN J., 1930, Report of the International Commission appointed by His Majesty's Government in the United Kingdom of Great Britain and Northern Ireland, with the approval of the Council of the League of Nations, to determine the rights and claims of Moslems and Jews in connection with the Wailing Wall at Jerusalem, UNISPAL doc A/7057-S/8427, 23/02/1968.

Lowenthal David, 1998, The Heritage Crusade and the Spoils of History, Cambridge, Cambridge University Press.

Lundsten Marie Ellen, 1978, "Wall Politics: Zionist and Palestinian Strategies in Jerusalem, 1928”, Journal of Palestine Studies, 29, pp. 3-27.

Nom De Deu Joao, 1987, Relatos de Viajes y Epistolas de Peregrinos Judios a Jerusalén, Madrid.

Orr Akiva, 1983, The unJewish State: the Politics of the Jewish Identity in Israel, London, Ithaca Press.

Peters Francis Edward, 1985, Jerusalem, Princeton, Princeton University Press.

RABINOVICH Abraham, 1972, “Experts doubt 'little Kotel' ever used by Jews for prayer”, The Jerusalem Post, 16 February.

RABINOwITZ A., 1969, "Diggers and prayers dispute new section of the Wall”, The Jerusalem Post, 22 July, p. 8.

RICCA Simone, 2007, Re-inventing Jerusalem. The Reconstruction of the Jewish Quarter after 1967, London, New York, IB Tauris.

Rivin A., 1974, Ishim be'Ir haNezah [Personalities in the eternal city], Tel Aviv, Alef.

Rubinstein Daniel, 1995, The Mystery of Arafat, Vermont, Steerforth Press.

SAID Edward, 1995, "Projecting Jerusalem”, Journal of Palestine Studies, XXV-1, pp. 5-14.

SCHLEIFER Abdullah, 1972, The Fall of Jerusalem - 1967, New York, Monthly Review Press.

Seidemann Daniel, 2007, “The Events Surrounding the Mughrabi Gate - 2007: A Case Study”, unpublished report for Jerusalem Old City Initiative (JOCI).

Siegel Judy, 1974, "Contrast between night and day crowds at Wall for Tisha B'Av", The Jerusalem Post, 29 July, p. 2.

STORPER-PÉrez Danielle, 1989, Au pied du mur de Jérusalem, Paris, Éditions du Cerf.

Survey of Palestine, 1946-1947, London: Her Majesty's. Stationary Office (Reprinted by The Institute for Palestine Studies), Washington D. C., 1991.

TAMARI Selim, (ed.), 1999, Jerusalem 1948, The Arab Neighborhoods and their Fate in the War, Jerusalem, Institute of Jerusalem Studies.

Tiвawi Abdul Latif, 1978, The Islamic Pious Foundations in Jerusalem, London, The Islamic Cultural Centre.

-, 1980, "Special Report: the Destruction of an Islamic Heritage in Jerusalem", Arab Studies Quarterly, 2-2, pp. 184-185.

Tunbridge John, Ashworth Gregory, 1996, Dissonant Heritage, Chichester, John Wiley \& Sons Ltd.

WILson Charles William Sir, 1876, Ordinance Survey of the Old City of Jerusalem Jerusalem Map 1:2500, London, George E. Eyre and William Spottiswoode for Her Majesty's Stationery Office.

XXX, 26 July 1974, "Plea to radio, TV to allow live coverage", The Jerusalem Post, p. 3.

Zerubavel Yael, 1995, Recovered Roots, Chicago and London, The University of Chicago Press. 


\section{Abstract}

The article analyzes the transformation of the Wailing Wall area after 1967. The Wall has been considered within an architectural and planning perspective presenting the urban transformations made to underline its 'eternal' centrality. The role of the Wall in shaping Israeli national identity has been discussed through the lenses of the recent heritage studies theories. It is argued that Israel needed physical, tangible symbols to sustain its claims on the city and that the reconstruction of the whole area defined as "Jewish Quarter", and particularly the creation of the large Plaza in front of the Wailing Wall, were meant to give the State of Israel an "incontrovertible" proof of its historic rights on the city.

Key words: Jerusalem, heritage, Wailing Wall, nationalism, conservation.

\section{Résumé}

Cet article présente les modifications de la zone devant le Mur des Lamentations après 1967. Dans le cadre d'une réflexion menée à l'échelle de l'ensemble de la vieille ville de Jérusalem, le Mur a été analysé du point de vue architectural et urbain en soulignant les transformations qu'il a subies afin de devenir l'élément clé de la "capitale éternelle "du pays. Les études récentes sur le concept de patrimoine ont fourni les bases théoriques de cette analyse du rôle du Mur dans la formation de l'identité nationale israélienne. L'article affirme que l'État d'Israël avait besoin de symboles physiques et tangibles qui puissent confirmer son droit de possession de la ville et souligne comment la reconstruction d'un secteur entier de la vieille ville renommé "Quartier Juif", ainsi que la création d'une large esplanade devant le Mur des Lamentations, avaient pour fonction de donner une preuve "incontestable" des droits historiques d'Israël sur la ville de Jérusalem.

Mots-clés : Jérusalem, patrimoine, Mur des Lamentations, nationalisme, restauration.

\section{Resumen}

Este artículo pone el foco en los cambios desde 1967 en el espacio delante del Muro de las Lamentaciones. contextualizado en una reflexión incluyendo toda la ciudad vieja de Jerusalén; el Muro es examinado desde el punto de vista arquitectural y urbano, centrándose la análisis en las transformaciones que sufrió para convertirse en el elemento clave de la capital "eterna" de Israel. La investigación reciente del concepto de patrimonio es la base teórica de esta análisis del papel del Muro en la formación de la identidad nacional israelí. El artículo afirma que el Estado de Israel carecía de simbolos físicos tangibles para poder sostener su derecho de propiedad de la ciudad. El articulo alega que la reconstrucción de todo el Barrio Judio de la ciudad vieja y la creación de una plaza ancha delante del Muro de las Lamentaciones tenían como objetivo ser pruebas irrebatibles de los derechos históricos de Israel sobre la ciudad de Jerusalén.

Palabras clave: Jerusalén, patrimonio, Muro de las Lamentaciones, nacionalismo, conservación. 